\title{
Ensino de História e Nação na Propaganda do "Milagre Econômico"*
}

Luis Fernando Cerri Universidade Estadual de Ponta Grossa - PR

\section{RESUM O}

A ação da publicidade referente a temáticas políticas sobre a formação da consciência histórica éo objeto deste texto, que rel ata a pesquisa de levantamento de peças publicitárias de instituições públicas e privadas no período do chamado "milagre econômico", publicadas em revistas de circulação nacional, selecionando as que eram relativas a três temáticas básicas para a formação da identidade nacional: o sujeito, o tempo e o espaço relativos à nação brasileira. Apresenta-se apenas o tema do Brasil-sujeito a título de exemplo do procedimento da pesquisa realizada, composto pel a análise de anúncios e pela utilização dos mesmos como ponto de partida para o depoimento de pessoas comuns que viveram o período.

Palavras- chave: História e ensino; consciência histórica; identidade nacional.

\section{ABSTRACT}

The article deals with yhe links between advertising, politics and historical counsciousness. M y research examines the advertises produced by public and private institutions published in national magazines during the period called "milagre econômico" (1970's). Three main themeswereselected: thesubject, thetime and the space related to the Brazilian nation. Here, I will only discuss the first theme - Brazil as subject - relating the advertises to the statements of common people of the period.

Keywords: History and teaching; historical counsciousness; national identity.

Que pensam os brasileiros do Brasil e de sua história? Que significados atribuem à nação e ao relacionamento entre os seus componentes? Em atenção a essa problemática, este trabal ho quer discutir a consciência de Brasil formada durante o regime militar, sua reversão ou não nos dias atuais, sua permanência, residual ou não. Até que ponto esta consciência formada pela propaganda dos governos dos generais (bem como a propaganda de seus colaboradores na sociedade civil) ainda está presente entre nós,interferindo nas relações entre as pessoas, na história que se ensina e que se aprende dentro e 
fora da sala de aula? A té que ponto ela ainda constitui obstáculo no longo e lento processo de construção de uma sociedade democrática? Ela inova em relação à propaganda nacionalista no Brasil, ou constitui um elo coerente num longo processo de nacionalização autoritária do território? Enfim, até que ponto esta consciência nos constitui, chegando a participar dos nossos pensamentos e atos, a ponto de não nos apercebermos dela?

Do ponto de vista da pesquisa do ensino de história, este estudo contribui para uma ampliação do campo, incluindo também os processos educativos que ocorrem através dos mei os de comunicação de massa, considerando que este é um dos desafios contemporâneos para esta área da pesquisa em Educação, na medida em que este novo século parece indicar um crescimento do papel das diversas mídias na formação educacional dos cidadãos, ocupando espaços cada vez maiores dentro efora da escola. 0 ponto de partida desta ampliação está nos estudos que, no decorrer da década de 1980 e 1990, tiveram um importante papel no assentamento das bases do estudo da História do ensino da História no Brasil,e cuja preocupação central esteve no estudo de diversos aspectos da disciplina (currículo, material didático, objetivos, utilização político-ideológica) em relação ao seu contexto de origem¹.

Assim, pensar historicamente no ensino de História é dedicar-se ao estudo das formas e dos processos pelos quais são constantemente feitas e refeitas as múltiplas consciências da história ao longo do tempo. As imagens de Brasil formadas pela propaganda do perío do em foco compõem uma consciência histórica que, como tal, é intrinsecamente identitária, como é histórica (no duplo sentido de datada e de algo que faz referência ao tempo histórico) toda identidade político-territorial.

\section{EnSINO DE HISTÓRIA E CONSCIÊnCIA HISTÓRICA}

Para Klaus Bergmann, a didática da história vai muito além da discussão sobre métodos e técnicas, e o estudo da formação e da dinâmica da consciência histórica faz parte de seu campo². É importante compreender a história que se aprende fora da relação pedagógica escolar, porque ela é apenas um dos momentos do aprendizado da H istória por parte dos alunos: muitos dos seus conceitos sobre o tempo, sobre identidade,sobre o passado, são aprendidos antes, fora e concomitantemente ao ensino formal. Os alunos, portanto, chegam à aula de H istória carregando concepções, noções, idéias, conceitos, preconceitos e informações cujo aprendizado não foi controlado pelo professor ou pela escola, mas que teve origem na experiência pessoal, no convívio com os mais velhos e seus conhecimentos, no contato diário com os meios de 
comunicação de massa,notadamente a televisão. Contribuir para a compreensão desses processos não-formais de aprendizado da H istória é útil em vários aspectos, principalmente para identificar eventuais fatores que determinam ou minam os limites de aprendizado e condicionam a compreensão da História, bem como para informar um processo educativo que se pretenda crítico, criativo e transformador.

Podemos conceituar a consciência histórica primeiramente pelo "espaço" que ela ocupa, ou seja, pelos condicionamentos que impõe à vida social, pelas condições das quais participa no processo de estabelecimento dos grupos humanos e de seu inter-relacionamento. Referimo-nos, em primeiro lugar, à necessidade humana de estabel ecer significados para o(s) grupo(s) do(s) qual(is) se participa, significados que se encontram - não exclusivamente - no passado, no presente e no futuro que se constrói e que se imagina para a coletividade 3 . D esta forma, a consciência histórica é o nome que estamos atribuindo a esses significados que são construídos em (e/ou por) cada grupo humano sobre si próprio, caracterizando-se no tempo e no espaço.

Para H eller, a consciência histórica tem diversos estágios, desde o momento em que um dado grupo cria as normas, substituindo com elas osinstintos (em que o sistema mítico do grupo legitima-o e significa, para ele, a origem do Universo, e em que o grupo é identificado à humanidade) até a consciência do mundo como histórico. N esse momento um dado grupo, após haver tomado consciência de que a humanidade o transcende, concebe o mundo como histórico, no sentido de construção humana (desencantamento), relativizando a própria cultura a partir de outras, no tempo e no espaço, até a consciência de que a história não marcha indel evel mente para o progresso (diante de eventos como o H olocausto, a explosão da bomba atômica sobre H iroshima, o Gulag ...), que a racional idade e a ciência não dão conta da evolução humana e de que o futuro é missão de cada um e de todos. Nesse percurso, teríamos chegado à configuração contemporânea da consciência histórica.

Para Hans-Georg Gadamer, este seria o momento de maior angústia da humanidade. Ele considera que apenas a atual configuração da consciência histórica seria consciência histórica por excelência,sendo que nos outros momentos essa consciência não se verificaria. Para isso, define a como “o privilégio do homem moderno de ter plena consciência da historicidade de todo presente e da relatividade de toda opinião"4. Isso merece uma reflexão própria, pois o que se afirma é referenciado apenas ao grupo que teve acesso tanto à educação formal quanto a uma formação humanista e laica, bem como à informação mundializada, e que é capaz de pensar desta maneira no conjunto das sociedades modernas. A consciência histórica não está referida, portanto, ao conjunto das sociedades hoje existentes, enem mesmo nas socieda- 
des centrais em sua inteireza, dada a heterogeneidade cultural presente. Portanto, o que Gadamer chama de consciência histórica é algo restrito, uma espécie de estágio atingido por alguns seres ou subgrupos humanos, "uma posição reflexiva com relação a tudo o que é transmitido pela tradição" ${ }^{5}$. Seu contrário seria, provavelmente, a "inconsciência” histórica, ao passo que na leitura de H eller não é possível pensar nesta oposição (com / sem consciência histórica), mas sim numa multiplicidade de consciências em diversos estágios diferentes. Se não tomarmos a leitura de Heller dentro de uma chave etapista ou evolucionista, podemos imaginar que não é possível que apenas alguns seres humanos tenham chegado à consciência histórica ou que a mesma seja algo a ser atingido - pois ela é inerente ao gênero humano, seja qual for a situação cultural de cada grupo ou pessoa.A consciência histórica existe em várias configurações que, concluímos, podem coexistir pela característica multicultural das sociedades contemporâneas, por mais diver so que possa ser 0 que ocupa o lugar da idéia de "história” em cada grupo.

M arc Ferro, em A H istória Vigiada, afirma a existência de diversos focos da consciência histórica em cada sociedade: as instituições (em outras palavras, a história oficial, legitimadora da dominação), os setores de oposição ao poder (que compõem o que Ferro chama de contra-história) e outros focos esparsos.

0 conceito de consciência histórica, com o qual trabalhamos, foge à oposição de Gadamer (consciência / não-consciência) e tangencia a abordagem plural de Ferro (que entretanto também se sustenta central mente na dualidade poder / resistências na produção dos focos), para retomar uma idéia que vem do conceito de senso comum em Antonio Gramsci 6 : o queas pessoas em geral pensam é fruto de uma sedimentação histórica: idéias, valores, imagens ligadas à dominação ideológica em períodos anteriores não desaparecem com a desestruturação das classes dominantes e da estrutura de poder anterior. Pelo contrário, seus fragmentos permanecem, com intensidade variável sobre a forma das pessoas se definirem e compreenderem o mundo. Portanto, a "filosofia das multidões"7 não responde somente à ideologia dominante do tempo edo espaço no qual existe, mas também de outros fatores que a fazem incoerente, fragmentária e conservadora, mas ainda assim com um núcleo de "bom senso" que precisa ser desenvolvido pelo pensamento crítico dos intelectuais orgânicos para al cançar a transformação social. Essa idéia nos auxilia a imaginar um quadro em que múltiplas consciências históricas convivem: desde as que entendem a história como um jogo divino em que o ser humano só aparece como instrumento quase desprovido de capacidade autônoma de ação, até as que atribuem a uma determinada classe a tarefa de transformar a história e assim realizar o interesse da humanidade como um todo. Em 
suma, o conceito de consciência histórica neste trabalho é composto pela incorporação da idéia de que existem diversas formas de conceber o grupo em relação ao tempo, idéia esta implícita nas etapas da consciência histórica de Heller ; de Ferro, incorpora-se à idéia de que diferentes consciências históricas coexistem numa mesma sociedade; por fim, recorremos a Gramsci para afirmar que, da mesma forma que no senso comum, as concepções que formam as consciências históricas são compostas tanto por representações dominantes contemporaneamente quanto pela permanência de outras, quetiveram maior importância em outros momentos históricos.

\section{RECORTES: TEM PO, IM AGENS E PESSOAS}

A opção feita para investigar estas questões foi abordar a propaganda nas revistas semanais que teve por tema a nação e a nacionalidade, durante 1969 a 1973. Resolvemos nos ater a esse período por concentrar um momento de euforia, de otimismo nacional, em que tais mensagens aparecem em grande número e variedade. A baliza inicial é composta pelos primeiros tempos da vigência do Al-5 (baixado em 13 de dezembro de 1968), o que caracteriza 0 período em foco como de extrema centralização do poder político no Executivo, de acentuado estreitamento (quase obstrução) dos canais formais de participação política e de suspensão dos direitos civis do conjunto da população para a obra de neutralização ou extermínio das forças de oposição não-consentidas ao regime,cuja radicalização está intrinsecamente ligada a esta conjuntura. 0 marco final é o ano de 1973, em que ocorre o primeiro choque do petróleo, originando uma crise internacional que mina as bases do crescimento econômico acelerado deste período, iniciando sua decadência.Este marco final destaca uma das principais variáveis da situação que também caracteriza o recorte, que éo crescimento econômico que sustenta um surto de otimismo e de manifestações nacionalistas integradas aos interesses de legitimação política do regime.

Optamos por abordar o período a partir das fontes publicitárias, encontradas nas revistas informativas semanais ou quinzenais,tanto pela facilidade que encontramos de acesso às mesmas (o que não se dá, por exemplo, com 0 suporte televisivo), quanto por constituírem um véculo destinado ao principal sustentáculo do nacionalismo ufanista desse período (e também um dos grandes beneficiários do crescimento econômico obtido), que são as camadas mé dias,cuja importância para a formação da opinião pública é assaz conhecida.

Na pesquisa documental para esta primeira parte, percorremos as coleções das principais revistas informativas ${ }^{8}$ que circulavam no período: Cruzei- 
ro, Fatos e Fotos, M anchete, Veja e Visão. A penas estas duas últimas foram usadas como fonte para seleção de peças publicitárias, pelas características predominantes em sua publicidade. Escolhemos as peças publicitárias como fonte porque concordamos com a proposição de quea publicidadeéuma porta privilegiada para o imaginário das sociedades, uma vez que deve falar a ele para que tenha sucesso em sua função primordial, de comunicar evender idéias e produtos. Para Barthes, a mensagem publicitária age a partir de reservas do imaginário, cuja produção relaciona-se com a convivência social e o processo de educação que produz o enquadramento social dos indivíduos ${ }^{9}$. Desta forma, el ementos do imaginário (no nosso caso do imaginário nacional ), incrustados na propaganda estatal ou civil, "saltam aos olhos" do leitor, pois é para isto que essas peças da comunicação de massa são feitas.

Anna Figueiredo aponta, estudando as peças publicitárias nas revistas brasileiras do período de 1954 a 1964, que existe uma progressiva decadência do argumento de caráter coletivo, social, geralmenteligado ao élan desenvolvimentista. Esse apelo, que procurava vender o produto ou serviço apelando à consciência de participação do consumidor no desenvolvimento do País, passa a ser paulatinamente substituído, na visão da autora, por um apelo individualista, e que projeta a felicidade pessoal não mais no sucesso da coletividade, mas no sucesso individual e no consumo de determinados produtos. Desloca-se o eixo, portanto, do apelo ao cidadão para o apelo ao "eu" ${ }^{10}$, chegando mesmo a transferir para o consumo as realizações da esfera política, como a democratização, por exemplo. Mas o que nos chama a atenção é a permanência, no período que estudamos, do apelo ao cidadão, em algumas peças publicitárias oficiais e privadas. Longe de ter sido superado pelo apelo de felicidade via consumo pessoal, o apelo político em sentido amplo permanece em várias peças publicitárias em revistas destinadas a essas mesmas camadas médias ea setores mais al tos das camadas do proletariado. Esse fenômeno é concomitante com a febre otimista/nacionalista/ufanista então verificada, ligada aos altos índices de crescimento econômico nacional,urbanização, fortalecimento dos setores secundário e terciário da economia e acesso da classe média a bens de consumo e duráveis, conhecido no conjunto como "milagre econômico". É a adesão (ainda que momentânea e parcial) da sociedadea um determinado projeto nacional informado por uma visão de Brasil elaborada pelo alto, e que transparece na publicidade para permanecer alimentando essa adesão. Por este motivo, optamos por selecionar, entre as peças que continham esse caráter político, as que desenvolviam seu argumento dentro da temática da nação, e conseqüentemente da identidade nacional.

Este tipo de apelo publicitário é mais característico da publicidade das revistas Veja e Visão, escolhidas para a seleção de fontes desta pesquisa, ao 
passo que a publicidade em 0 Cruzeiro e na $M$ anchete caracteriza-se principalmente pelos anúncios despolitizados e voltados ao consumidor, e muito pouco ao cidadão.

A pesar de ser de grande importância a análise das mensagens dirigidas destinadas à ação sobre a consciência histórica/identidade nacional, não poderíamos nos furtar a problematizar, pel o menos, a recepção e com a reelaboração dessas mensagens por parte dos cidadãos. Para isso, optamos por contar com depoimentos orais de um grupo de colaboradores, a partir de sua leitura de al gumas das peças publicitárias que são anal isadas. D esta maneira, propiciamos a utilização da fonte publicitária como mediação para a memória ea enunciação da consciência histórica (em sua parcela relativa à nacionalidade), aproveitando-nos da sua condição de suporte de elementos verbais e não-verbais, que trazem consigo um legado involuntário exemplar do pensamento autoritário brasileiro nesse período, através do qual se podem realizar a sua análise e a sua crítica.

No lado dos "emissores", as revistas analisadas constituem espaços privilegiados de expressão de setores al iados ou que não estão em conflito direto com a ditadura militar. Assim,manifestam-se através da publicidade variados setores do Estado (principalmente as empresas públicas) e da sociedade civil (notadamente as empresas particulares). Este canal permite a expressão de conceitos, opiniões e julgamentos de valor sobre a conjuntura nas quais se inclui uma determinada idéia de Brasil e de sua história, o que se constitui num interessante objeto para observar uma produção e divulgação da história que não passa pelas instâncias tradicionalmente estudadas na área do ensino da História, ou seja, a Universidade e a Escola fundamental e média. Estamos diante de um processo educativo ${ }^{11}$ não-formal, tendo a história como um de seus focos principais, que é produzido por parcelas do Estado e da sociedade civil numa situação privilegiada de poder político eeconômico, e re cebido pelas pessoas através de um meio de comunicação de massa.

Se compreendemos que os enunciados dessa publicidade ${ }^{12}$ são necessariamente dialógicos, pois ao mesmo tempo devem transmitir uma mensagem, mas considerar que ela é dirigida a interlocutores dos quais se faz uma dada idéia e dos quais se espera uma resposta (mesmo que não-verbal), e se compreendemos que o ensino da História é composto por um grande conjunto de enunciados, podemos advogar a contribuição do presente trabalho para as pesquisas sobre 0 ensino de H istória na medida em que o objeto estudado - um dado aspecto da consciência histórica - é o interlocutor privilegiado dos enunciados que ocorrem no contexto desta ação educativa, e portanto é constituinte do discurso da H istória para a escola. Estudar, portanto, a produção, a emissão e a resposta a mensagens publicitárias cujo con- 
teúdo gira em torno dos mesmos temas abordados pela disciplina é importante para a compreensão dos próprios discursos que a disciplina elabora, e em conseqüência, para a análise dela.

A outra grande questão geral que se coloca é saber como os indivíduos interagiram com o que lhes foi ensinado pela propaganda de caráter político (no sentido amplo) do regime militar e seus apoiadores. N ão nos basta identificar e analisar as mensagens transmitidas à massa, uma vez que nos preocupamos com a formação da consciência histórica, dos condicionantes do pensamento das pessoas sobre a sua identidade no tempo, a partir dos quais o professor de História trabalha. A questão, em suma, desdobra-se em dois aspectos: como as pessoas pré-identificadas com a nação e submetidas a esse processo educativo tendo a história / a nação por conteúdo apreenderam o Brasil que lhes foi comunicado? Que papel ele desempenha em suas memórias pessoais, em suas identidades?

Estas perguntas crescem em pertinência se considerarmos a já comentada possibilidade do destinatário da mensagem das mídias em reelaborar a idéia que recebe a partir de seu próprio universo interior. Eco afirma que,par ticularmente no que se refere à comunicação de massas, a norma é a decodificação aberrante, ou seja, divergente do significado que foi elaborado pelos emissores $^{13}$. A pesar disso ser mais importante para a mídia queEco está estudando neste texto, a tel evisão, cujo público é composto por uma massa indiferenciada de receptores, a afirmação não é irrelevante ou inválida para a mídia impressa das revistas, em que o público é mais restrito, mas que se trata igualmente de meio de comunicação de massas. Porque mesmo entre pessoas que dominam os códigos escritos e que são portadoras de um certo poder aquisitivo que lhes permite o acesso às publicações, o universo de referências, experiências e modos de interpretação é presumivelmente heterogêneo. Ainda que a interpretação da mensagem central seja mais ou menos comum a todos, a percep ção dos detal hes, dos elementos expressivos e seu significado segue uma lógica pessoal, e o grau de compartilhamento dessa lógica com outras pessoas pode ser mais ou menos amplo, ou mesmo nenhum. Pode-se mesmo afirmar, no limite, que a comunicação de massas não cria mensagens padronizantes e homogeneizantes, mas sim mensagens que permitam leituras variadas, em que os diferentes grupos possam adaptar a interpretação ao seu ponto de vista. Isto faz sentido também dentro da lógica de mercado, pois o maior sucesso está posto para idéias e produtos veiculados através de mensagens que não neguem crenças, valores e opiniões de nenhuma parcela da sociedade, se possível, através da renúncia a mensagens que sejam ou pare çam vincular-se a parcelas estritas da sociedade.

D efinimos, portanto, que o que estava a ser feito era criar uma situação 
para as pessoas que viveram aquele momento expusessem o que aquelas peças publicitárias significam para elas, a que imagens, idéi as e sensações se ligaram. M as há, de saída, uma condição que precisa ser reconhecida. N ão é mais possível apresentar as peças publicitárias às pessoas para as quais foram potencialmente endereçadas, pois essas pessoas não existem mais. M esmo que a maior parte delas esteja viva, o contexto no qual aquela comunicação foi empreendida não existe mais, e as pessoas que o viveram estão modificadas por quase 30 anos de outras experiências pessoais, e vivendo num outro contexto que interfere sobre as condições de recepção e análise da mensagem publicitária. Portanto, temos um determinado conjunto de mensagens num processo de comunicação mediado pelo tempo e pela memória das pessoas às quais estão sendo atualmente destinadas. A presente pesquisa constitui-se, então, numa proposta de estabelecer uma comunicação com mensagens do passado, e coloca em tela as decodificações duplamente aberrantes (pela característica intrínseca à mídia e pelo fato de ser feita por um grupo distinto daquel eao qual se destinava), queno entanto compõem a fonte que nos permite estudar a reelaboração feita por al guns sujeitos dessas mensagens, ressalvados os condicionamentos aqui postos ${ }^{14}$. N ão é essencial que os anúncios tenham sido efetivamente vistos na época em que foram publicados, pois se assim fosse criaríamos uma situação de releitura, que em pouco se diferencia de uma primeira leitura, exceto pelo fato de trazer consigo alguma expectativa de resgate da impressão causada na primeira vez ${ }^{15}$.

No lugar de uma perspectiva quantitativa, preocupada com a representatividade e a possi bilidade de generalização, pautamo-nos por uma perspectiva qualitativa, em quea importância está no significado subjetivo da experiência de cada um dos entrevistados. A validade do estudo não se assenta na sua representatividade estatística ou na condição paradigmática dos depoentes, e está calcada na experiência única e irreprodutível dos sujeitos entrevistados. Renuncia-se assim, no estudo, às afirmações universal mente válidas sobre as regularidades nas interpretações dos depoentes, e adota-se uma perspectiva subjetiva, em quea possibilidade de generalização das afirmações é posta para o sujeito que lê os resultados da pesquisa e avalia a sua experiência pessoal e as experiências com as quais travou contato no decorrer de sua vida. Diferentemente de índices de alfabetização ou curvas de preço, as peculiaridades do objeto estudado - memórias e experiências a partir de el ementos de comunicação do passado - conduzem a esta perspectiva em que o subjetivo impera, em que a generalização de conclusões e quantificação de resultados não é adequada. Ou, usando os termos de Lüdke e André ao comentarem os estudos de caso: "Em lugar da pergunta: este caso érepresentativo do quê?, o leitor vai indagar: o que eu posso (ou não) aplicar deste caso na 
minha situação?" ${ }^{16}$ A generalização do presente estudo não se dá pela sua capacidade de mostrar a realidade, mas de expressar um fragmento específico e irrepetível da mesma, de modo que o sujeito leitor seja o juiz provisório da possibilidade de encontrar el ementos comuns em outras situações, na medida em que compara os dados do estudo com aquilo que traz desua experiência e conhecimentos.

Cada depoimento foi compreendido como um foco capaz de representar a encruzilhada entre a vida individual e social, do qual determinadas informações pudessem ser obtidas pela explicitação das marcas coletivas nas falas individuais,e pela leitura individual de produtos da comunicação demassa. Portanto, apesar de restringirmos de partida a capacidade de generalização estatística das opiniões a serem colhidas por este método, apostamos nessa capacidade do discurso individual de não apenas revelar a si próprio, mas ao mundo social no qual existe, com suas estruturações, valores,e assim por diante. Também porque, a rigor, segundo Halbwachs, não há memória individual, pois até nos momentos em que se vive al go na mais absoluta solidão, o meio que compôs a mente de cada um se faz presente nos códigos, nas sensações, opiniões, enfim, fragmentos do coletivo ou de outras pessoas que, indiretamente, não nos deixam na solidão absoluta E neste emaranhado, Halbwachs procura estabelecer o que seria o viés do indivíduo:

No mais, se a memória coletiva tira sua força da duração do fato de ter por suporte um conjunto de homens, não obstante el es são indivíduos que lembram, enquanto membros do grupo. Dessa massa de lembranças comuns, e que se apóiam uma sobre a outra, não são as mesmas que aparecerão com mais intensidade para cada um deles. Diríamos voluntariamente que cada memória individual éum ponto de vista sobre a memória coletiva, que este ponto de vista muda conforme o lugar que eu ali ocupo, eque este lugar mesmo muda segundo as relações que mantenho com outros meios. $N$ ão é deadmirar quedo instrumento comu $m$, nem todos aproveitam do mesmo modo. Todavia, quando tentamos explicar essa diversi dade, voltamos a uma combinação de influências que são, todas, de natureza social ${ }^{17}$.

Dentro dessa perspectiva, desistimos da preocu pação com uma representatividadenacional ou mesmo regional, emantendo os critérios definidos acima e assumindo uma caracterização de um estudo de experiências (o "caso", aqui, é cada indivíduo entrevistado), resolvemo-nos a selecionar os entrevistados a partir de um grupo de idosos reunidos pel o projeto UniversidadeAberta à Terceira Idade,l i gado ao Departamento de Educação da Universidade Estadual de Ponta Grossa, valendo-nos da metodologia dos depoimentos orais 
com entrevistas semidirigidas. Essa metodologia, cremos, foi a mais adequada para responder às nossas indagações, por permitir que entrássemos em contato com as lembranças e análises de "pessoas comuns" sobre a propaganda do período estudado, recolhendo com a maior eficiência possível este material ao qual não teríamos acesso por meio de fontes escritas.

Garantindo o sigilo quanto à identidade de cada informante (o que, segundo percebemos,facilitava as respostas da maioria), foi possível realizar as entrevistas,aprofundando as respostas escritas e obtendo a análise de outras peças publicitárias, selecionadas dentre o conjunto das que foram trabalhadas na pesquisa em foco. A maioria das entrevistas foi realizada na sala usada pelo grupo na U niversidade nos horários em que estavam vagas e em que havia disponibilidade dos depoentes. A penas em dois casos a entrevista se deu no local de trabalho dos entrevistados, com seu consentimento eagendamento prévio. O utros três entrevistados foram integrados a esse grupo selecionado, incluindo pessoas que não participavam do grupo de Terceira Idade, mas que foram mencionados pelos que participavam como pessoas que, na cidade, também teriam algo a dizer sobre os assuntos postos na entrevista. Dois deles, entretanto, entraram no grupo de entrevistados principalmente porque constituem as pessoas consideradas como o oposto do que a propaganda política dominante do período esperava dos ci dadãos. Identificando-se como comunistas, constituíam o "outro" necessário a qualquer processo de identificação, inclusive o nacional, e que sofreram na pele as conseqüências de sua divergência em relação ao poder ditatorial. Consideramos fundamental a fala desses personagens, e uma vez que não divergiam do perfil traçado (alvo potencial das peças publicitárias analisadas), resolvemos incluí-los, o que acabou por enriquecer o grupo de entrevistados. Optamos por não diferenciar entre os participantes e não participantes do grupo, como maneira de garantir que o levantamento do perfil de cada um não denotasse a sua identidade. Em alguns casos isso não é possível, dadas as trajetórias de vida incomuns de alguns participantes, o que não nos incomoda, tendo em vista que as pessoas cujos perfis acabam por possi bilitar a sua identificação são pessoas que não fizeram restrições quanto ao seu anonimato ou revelação de sua identidade. D os depoimentos dos que se mostraram reticentes quanto a esta questão, foram omitidas al gumas informações no sentido de resguardar a identidade dos entrevistados.

O título de cada um dos subtítulos posteriores inclui a palavra "diálogo". Estamos compreenden do este conceito dentro da discussão sobre a comunicação verbal de Bakhtin, entendendo os anúncios impressos como componentes de um gênero do discurso e cada um deles, isoladamente, como um enunciado, com todas as suas características: é delimitado por enunciados de 
outros falantes, existe no contexto imediato da realidade, bem como possui significação plena e capacidade (ou necessidade) de suscitar uma atitude responsiva no seu interlocutor ${ }^{18}$. O u seja, o diálogo (no sentido da al ternância de enunciados provindos de diferentes locutores) é o ambiente em que os enunciados - no nosso caso, os enunciados da propaganda - se dão $0^{19}$. Insistimos no termo diálogo porque, segundo Bakhtin, o papel dos outros (dos queirão responder ao enunciado) é fundamental no processo de elaboração deste, e portanto aqueles não são ouvintes passivos, mas participantes ativos da comunicação, mesmo quando estão aparentemente no papel de absolutos receptores, sem condição de dirigir uma mensagem responsiva ao elaborador do enunciado, porque o "índice constitutivo do enunciado é dirigir-sea alguém, estar voltado para o destinatário"20.

Um texto como este que está diante do leitor impõe ao autor algumas escolhas.A pesquisa analisou uma série de quase três dezenas de mensagens publicitárias e submeteu-as à leitura dos entrevistados. Elas foram selecionadas e organizadas em torno de três temáticas centrais da identidade nacional entre al gumas outras possíveis - que foram a subjetividade, a temporalidade e a espacialidade da nação. O ptamos aqui por trazer apenas uma peça publicitária e os respectivos comentários e excer tos das entrevistas, de modo a permitir que o leitor vislumbre uma amostra do procedimento e dos resultados do trabalho.

BRASIL - SUJEITO

A história nacional tal como é ensinada a partir dos currículos oficiais, apesar de ser apenas uma das histórias possíveis, é a história à qual os cidadãos aderem como sua, por opção de integrar-se ao grupo ou por absoluta falta de conhecimento de outras possibilidades de registro e interpretação do tempo com que se identificar, inclusive a própria memória experienciada em grupos menores. E cria-se, a partir de um processo educativo (escolar e extra-escolar), uma instável ligação, que é a memória histórica, ou seja, a generalização de um conhecimento obtido a partir de um determinado tipo de pesquisa histórica que tem a nação por critério essencial,ao lado de uma postura cientificista (que poderíamos identificar à Escola M etódica ou Tradicional), que acaba por um incorporar-seà memória coletiva como a lembrança de al go vivenciado pelo grupo todo. Com isso, a história nacional torna-se memória comum na qual será necessário fazer caber a multiplicidade e a diferença, assimilando-as quando possível ou aniquilando-as (pelo silêncio) 
quando colocam sob suspeita a unidade do trançado de narrações da história nacional ${ }^{21}$.

É sob esta perspectiva de unicidade quea história nacional recorre à "personalização" do Brasil, o que fica muito claro no desafio feito pela propaganda do regime militar 22: "Brasil, Ame-o ou D eixe-0." A nação é posta como sujeito da história, e para símbolo de massa é constituído (na complexidade de sujeitos e tempos do processo histórico de formação da nacionalidade) um indivíduo coletivo, com as atribuições que se confere,na modernidade, à condição individual: vontade, autodeterminação, capacidade de atuar sobre a natureza e os outros indivíduos, e que se move dentro da situação incômoda de ser o resultado de uma coletividade de indivíduos e, ainda assim, um "outro" indivíduo que se pode amar, deixar, receber prêmio ou punição.

Um dos efeitos desse mecanismo éfacilitar a identificação entre a vontade da nação e a do regime vigente em cada conjuntura, o que transforma a oposição política a um projeto em oposição à coletividade nacional com a qual os indivíduos se identificam, e da qual, enquanto cidadãos, participam politicamente.

Se tomarmos em conta a anál ise que Roland Barthes faz da linguagem publicitária, considerando que a mesma integra três mensagens integradas (a denotativa - a mensagem em seu significado bruto, sem interpretação, queé apenas a leitura do código lingüístico ou imagético; a conotativa - composta de tod os os sentidos "segundos" ou associados à mensagem denotativa, as inter pretações da mesma; e por fim a referencial, que é a enunciação da marca do produto $)^{23}$, poderemos perceber que neste anúncio, o texto de chamada,no aspecto denotativo, compõe na verdade um trocadilho entre "comprar" e "cumprir", cuja função é associar os dois atos: a compra das O RT N s com o imaginário nacionalista, militarista e otimista do momento, em que o "Brasil"aparece como credor de obrigações a serem cumpridas / compradas. 0 trocadilho é a ponte da denotação para a conotação, em que se associa um produto vendido pelo Estado através da Bolsa de Valores de São Paulo à nacionalidade.

M as, então, quem espera que as ORTN s sejam compradas? O "Brasil" é um sujeito coletivo demasiado geral para se entreter com uma questão tão prosaica quanto papéis do Tesouro Nacional postos no mercado financeiro; quem se beneficia da venda desses papéis é a administração conjuntural do Estado, isto é, o governo, e seus associad os no mercado financeiro. Assim, 0 sujeito "Brasil", dotado de legitimidade,identificação com cada indivíduo brasileiro, e uma longa duração, é anteposto ao governo militar passível de questionamentos, exterior ao indivíduo, e de duração efêmera em termos históricos. A ocultação de um sujei to histórico específico por um sujeito abstrato e 
coletivo é so bretudo uma operação de legitimidade: identifica um governo (que é caracterizado pela parcialidade - não é a nação, mas parte dela - e por ser restrito no tempo) à totalidade e atemporalidade do "Brasil", nome e símbolo de identificação de todo um grupo humano. E é uma típica operação ideológica de generalização social de um pensamento, operação à qual o conceito de nação presta-se por excelência.

No discurso nacionalista da, na e sobre a história brasileira, o uso do termo e do conceito de "Brasil"serve como mecanismo de indeterminação dos sujeitos históricos por trás dos processos narrados; isso contribui com um sentimento e uma idéia de unicidade (essencial, como já se disse, ao sentimento nacional), efavorece também a possibilidade da mai oria dos cidadãos aderir a essa história,assumindo-a como sua. Com esse proceder, generalizam-se para o passado coletivo as decisões, erros, vitórias,crimes, ganhos, que foram de al guns grupos específicos no decorrer da história. Uma das fontes,aliás, do anacronismo que permite a muitos discursos, de caráter pedagógico, na sua maioria, estabel ecer um al inhamento dos sujeitos contemporâneos com personagens históricos, convertendo a todos em "nós", ou "o nosso lado".

Em suma, os el ementos dessa nossa análise levam a crer que a interpretação desejada pelo elaborador desta peça gira em torno do apelo ao dever oriundo da nacionalidade expresso no trocadilho do texto de chamada (cumprir / comprar obrigações). O sucesso desse apelo ao dever depende do esclarecimento do trocadilho, ou seja, da passagem efetiva da leitura do nível denotativo da mensagem para o conotativo, usando os termos de Barthes. 0 apelo é reforçado pela figura da mão queaponta eintimida,afirmando quea mensagem refere-se ao leitor mesmo, não a uma massa anônima. 0 objetivo é vincular as O brigações Reajustáveis do Tesouro Nacional (ORTN) aos deveres da condição de brasileiro para vendê-las, argumentando, secundariamente, com a lucratividade e segurança do investimento. As falas abaixo mos tram de que maneiras essas mensagens interligadas são lidas pela memória, pela subjetividade e pelas experiências e opiniões posteriores dos depoentes.

\section{LEITURAS E LEITORES DA PROPAGANDA DO “MILAGRE"}

No que se refere ao aspecto da leitura do texto de chamada (que divide com a ilustração a atração do olhar do leitor), percebe-se que, na maior parte dos depoimentos, o trocadilho não foi "desarmado" pelos leitores, prevalecendo a compreensão de que a peça solicitava o cumprimento das obrigações, em vez da compra das mesmas. Vale dizer, a maioria passou ao largo do aspecto conotativo, chegando de forma mais imediata à interpretação, à deno- 
tação. Este "salto" teve principalmente duas conseqüências: por um lado, permitiu a verbalização do imaginário do dever a ser cumprido em favor da nação, algo que vem de uma educação cívica que ocorre dentro efora da escola, em busca da maior parcela possível de cidadãos, desde pelo menos a estruturação do sistema educacional republicano; por outro lado, significou uma menor atenção ao aspecto referencial da mensagem publicitária, poisficou prejudicada a definição de qual era o produto vendido (as ORTNs) e a empresa vendedora. Portanto, essas duas conseqüências da característica do enunciado referem-se respectivamente a um apelo político e a um apelo econômico, de consumo. Podemos adiantar também que, nos casos em que esse reconhecimento da marca ocorreu, a sua avaliação e a do seu apelo mercantil foram condicionadas pela imagem de Brasil utilizada na parte conotativa/denotativa da mensagem, segundo a interpretação / sensibilidade do entrevistado.

Comecemos pel os depoentes em cuja leitura predominou o aspecto referencial da mensagem. 0 que chama o olhar da sra.A, na peça publicitária, a julgar pela sua fala, é a "assinatura" que revela que se trata de uma comunicação da Bolsa de Valores de São Paulo, da qual tem uma interpretação negativa, como uma instituição estritamente exploradora. Talvez isso se adicione à sua crítica, que recusa as insistentes cobranças dos deveres dos cidadãos sem a contrapartida do respeito aos seus direitos, o que por sua vez significa 0 cumprimento dos deveres por parte dos governantes (e esta "cobrança" é de fato uma das imagens que a peça mobiliza, ainda que pretenda passá-la de modo positivo):

Aqui eu entendi assim, essa Bolsa de Valores, que tira o dinheiro do pobre, que fazem, não é isso que quer dizer essa coisa? Eu entendi isso. Porque, você veja, quem tem dinheiro lá pra el es,para jogar, não sei o que éque jogam, não sei 0 que queé, não sei, acho que isso ... não sei o que, não entendi bem essa parte.Só achei muito feia [a figura da mão], não gostei. (A)

A última frase traz também uma apreensão estética do enunciado, que está ligada à figura, com a qual não se estabelece uma relação prazerosa,mas sim incômoda e desagradável, em sintonia com o sinal negativo que se estabelece na leitura de A para toda a peça, marcada por um ceticismo em relação às exigências do poder político sobre o comportamento popular, em promessa que propõe a troca desse comportamento pela garantia de um futuro melhor. A sra. E também fez uma leitura em que o que aparece primeiramente é o aspecto referencial da mensagem: 
Aqui está fal ando assim [lênovamente o texto em tipos menores] Aqui pelo que eu entendi ele está falando sobre uma forma de ganhar dinheiro. Sobrea Bolsa deValores, quer dizer, as pessoas elas podem aplicar lá na Bolsa de Valores que elas têm muito mais ... assim, com mais renda, né?

A figura ela está com uma mão segurando, um pulso firme, né? Quequer dizer, que tá segurando al guma coisa, né? Eu acho que significa, quer dizer, segurando assim um pulso firme quer dizer que vocêteria que segurar ... entrar nesse plano aqui, né? Desde que tenha condição é isso aqui, né? Tendo condição é isso aqui, porque é isso aqui o que está ocorrendo. (E)

A fala se inicia pelo reconhecimento da marca e pelo estabelecimento de uma posição perante a mesma: não é negativa, como na fala da sra. A, pois concorda em geral com o enunciado, afirmando a necessidade de investir "nesse plano", mas percebe-se um certo distanciamento pessoal em relação ao produto, pois se aventa a possibilidade de não existirem condições financeiras para realizar o investimento. A identificação da figura como uma mão fechada está presente no depoimento da sra.E,associada ao significado de necessidade de economia, de poupança, do contrário de uma atitude perdulária.

O utras lei turas referiram- se aos aspectos denotativos e conotativos da mensagem publicitária, concentrando-se no texto de chamada ou dando atenção também à ilustração da mão apontando. Como já adiantamos, foi comum a leitura aberrante do aspecto conotativo, seja no quese refere ao trocadilho cumprir / comprar, seja no atinente à identificação do que a figura representa. Prevaleceu em geral a leitura do "compre" como "cumpra", o que mostrou a força deste trocadilho em passar despercebido, cal cado na exaustiva exposição da idéia e dos termos ( de o Brasil esperar de cada um o cumprimento das suas obrigações), a ponto de causar sua naturalização e incorporação.

0 sr. C demonstra familiaridade com as mensagens, encontrando eco delas em sua memória, recordando a presença delas de forma difundida e generalizada:

Elas de uma forma geral me lembraram realmente, todas elas, o período de 64, eram coisas que eu via realmente. Todas elas eu via. M as elas não tinham assim, vamos dizer, uma coisa específica pra mim. Eu interpretei assim de uma forma geral. Porque veja, essa figura aqui. o Brasil espera que cada um cumpra suas obrigações, porque lá se falava isso, cumprir seu dever, né? (...) É, o tamanho da mão, ébem grande, os dedos, apontando para você. É isso aí. Eles usaram a propaganda, era uma coisa que estava nos ol hos de todo mundo, na época. Esseé igualzinho. Aí fala das O brigações do Tesouro Nacional, que na época estavam vendendo muito. Para tentar vender as O brigações. Por que essa figura não era 
para isso aqui, viu? Ela foi tirada de um outro contexto, foi usada pra fazer propaganda, mas ela aparecia em outra, o Brasil espera que cada um cumpra seu dever, compre suas ações, compre suas obrigações era cumpra suas obrigações, eles usaram, eles transformaram para fazer propaganda da Bolsa, que originalmente não era. (C)

Notemos o trajeto de leitura de C: parte, inicialmente, de uma não "tradução" do trocadilho, ou melhor, começa pelo aspecto conotativo da mensagem. Vai então para o aspecto referencial,indicando a compreensão do produto e da marca para só então, após relacionar a imagem com outra da qual se recorda (e não o recorda sozinho, como veremos, revelando um referencial icônico comum), desmontar o trocadilho. Neste percurso, o que acaba fazendo é indicar uma referência, em sua memória, de uma mensagem de participação da nação através do cumprimento das obrigações (interação majoritariamente política com o grupo), evocada pela presente mensagem, em que essa participação na nacionalidade vem mediada por um ato econômico, ou seja, comprar as ORTNs.

De uma forma mais exata,o sr. I faz a mesma identificação que $C$ daque la imagem (que originalmente tinha outra finalidade) e que é utilizada na peça em questão:

Propaganda muito inteligente, com forte apel o coletivista, não é? [folheia as várias peças publicitárias] Tá ven do que é uma coisa muito importante isso. [Iongo silêncio] M uito inteligente esse. [outro longo silêncio] Essa aqui puxa pro capitalismo firme. Mas o texto de chamada éum texto simpático: “O Brasil espera que cada um cumpra com suas obrigações". Isso é verdade.

E esse desenho, da mão ... Isso daí é mais ou menos cópia de propaganda que saiu nos Estados Unidos, que tinha lá o Tio Sam no tempo da guerra, apontando lá pro cidadão, "Você,e tá tá tá...", convocando pra guerra,mas é ...serve muito bem, né?

Ela puxa pra idéi a de compromisso, então, da pessoa com o país, né, isso é do regime militar. Não, aqui a intenção émais capital ista. E vê que a origem dela já veio de um cartaz americano. M as pena queninguém lê isso, eles só lêem o texto aqui de chamada, mais nada. Não é assim? (I)

Podemos ler neste fragmento uma identificação do caráter de apelo econômico constitutivo da peça, na visão del, embora ele hesite entre esta qualificação e a de um apelo político (do País, do regime), mostrando que a peça, para este sujeito, foi bem sucedida neste objetivo de vincular estas duas esferas da cidadania: a participação política com a participação econômica. 
Estamos diante de um dos grandes dilemas da cidadania nos últimos dois séculos, que se amplia do critério econômico típico dos primeiros pensadores liberais ( ou seja, só os que são proprietários podem participar da vida política, pois seu sustento não depende de outros) ao critério social (ou seja, participam os que pertencem à nação, independentemente de sua situação econômica), e que se nos afigura hoje como um retorno à primeira situação, pois os direitos cada vez menos são atribuições do homem político, mas do trabalhador e do consumidor, antes de mais nada ${ }^{24}$. Essa peça é sintomática não de uma passagem entre o apelo publicitário de caráter coletivo, político (ao desenvolvimento da nação, por exemplo) ao apelo ao consumo como fonte de satisfação individual ${ }^{25}$, mas de uma per spectiva que procura integrar 0 sentimento nacional à satisfação pelo consumo, a ser possibilitado pel o ganho com o produto financeiro anunciado.

No trecho a seguir apresenta-se um processo de desmontagem do trocadilho, ao mesmo tempo em que a decodificação da figura é feita de forma distinta daquela pretendida pelos seus elaboradores:

Bom, primeiro eu acho que a gente vai no caso ler a manchetezinha ali, né, o título: “O Brasil espera que cada um compre ...é .... compre suas obrigações? Compre? [ri] Se fosse eu, já tinha lido “cumpre”. É, esse daí dá um ... um caminho. Agora, como? Se for em termos econômicos, posso levar para o lado da responsabilidade, de assumir o próprio compromisso, queé uma mão fechada... Deixa eu ver se é bem uma mão fechada ... Porque, veja bem, aqui tem as letras menores. A gente não liga muito com isso. A gente vai ligar com a manchete, com 0 título, né, já vi que veio da revista Veja, de 70. Esse aqui éuma publicidade, de Bolsa de Valores,incitando as pessoas a aplicarem os seus recursos em al guma, aqui, como fala, as O brigações Reajustáveis, aplicação de juros,né,aqu eles juros que a partir de então ( ....). (D)

O u seja, a mão apontando é entendida como uma mão fechada, mas o "fracasso" da decodificação desta parte do enunciado não significa o fracasso do enunciado em si. Se o objetivo é garantir a captação das economias para o investimento nos papéis anunciados,a compreensão da figura como uma mão fechada também dá a sua parcela de contribuição, já que entrevistada associa a mesma à necessidade de poupança, de forma análoga à sra. E, que vê na figura um "pulso firme", "quer dizer que vocêteria que segurar".

A peça oportunizou a estruturação de algumas lembranças, e a vivência contemporânea de al guns entrevistados participou de forma mais decisiva deste rememorar, significando mesmo al gumas vezes uma elisão do passado. Este é aproximadamente o caso da sra.A, que manifesta uma postura cética, 
crítica e indignada, que não existia no período em que a peça foi publicada, mas que se desenvolveu a partir da morte do marido (situação em quea opressão imediata desaparece e as portas do mundo além do lar se abrem para ela) e da vivência da situação de pensionista, testemunhando as sucessivas humiIhações impingidas pelo poder público à maior parte das pessoas nesta situação, do que são exemplos as filas intermináveis para o pagamento dos benefícios ("Às vezes eu vou no banco receber meu ordenado, não tem vez que eu não vá que eu não venha triste ou chorando"). Estas vivências diluem o sentimento de amor à pátria, construído na infância, na escolarização, e mantido durante a maior parte da vida: em outro ponto da entrevista,a sra.A afirma que a bandeira nacional não passa de um pano, frase expressiva do desencantamento pessoal que experimentou para com a mística dos símbolos nacionais (e, em conseqüência, da nação que eles representam).

Defendemos quea posição não- crítica em relação aos deveres colocados pelo Estado, presente em 1970, entre outros motivos, deve-se a um relacionamento compreendido ou sentido como favorável com esta instituição. Pois o amor à pátria (um dos deveres do cidadão, segundo muitos) está alimentado pela reciprocidade com o Estado nacional, que responde com bem-estar social. De certa forma, isenta os governos militares ( "acho que cumpria" a sua parte,afirma que "os militares foram ótimos" e que pareciam ser mais humanos - visão que só se sustenta perante o desconhecimento ou desconsideração de algumas informações, como o desrespeito às liberdades civis e aos direitos humanos praticados com a anuência do regime ou resultado direto de suas políticas - ,não mercantilizando todas as coisas, como percebeque ocorre hoje, mas não os governos posteriores. Se por um lado podemos relativizar esta visão dos governos militares, uma vez que a depoente, no período, tinha suas percepções da vida nacional filtradas pela sua condição de submissa ao marido e ao lar, por outro lado podemos notar que ela estabelece um contraponto entre as políticas orientadas para a prevalência do mercado, características da atualidade, e um período de maiores garantias sociais, cujo desapare cimento é lamentado. Sobretudo a fala evoca um cansaço e uma intolerância que apontam para o esgotamento da postura dos sucessivos governos em exigirem sacrifícios da população em nome da comunidade nacional, que geralmente não foram acompanhados de uma compensação ou de um funcionamento correspondente por parte dos governos. No presente,este contrato de reciprocidade com o Estado - nação é percebido como rompido pela sra.A, perante as dificuldades financeiras que vivencia e presencia, e que entende como culpa dos que detêm o poder político ${ }^{26}$. É nesta chave que devemos ler a criticidade do depoimento de A: pela situação vivenciada no presente.

Esta propaganda também evocou lembranças desagradáveis para a sra.F : 
Tá demonstrando uma mão apontando. Eu acho que aqui tá apontando em parte 0 defeito do nosso governo. Porque tá muito difícil,né? Parece, que nem a gente diz brincando, parece um castigo. I sso na minha interpretação, porque esse você aqui, esse aqui você vai perder muita coisa, porque nós perdemos muito naquela época, naquele governo. 0 povo da agricultura, o governo pegou,não sei como é que chama aquilo, nos bancos,né, as economias da gente ... é, recambiaram, né? Daí que nós tínhamos, o povo que tinha alguma coisa no banco eles tomaram conta, né? M ais tarde o meu marido recuperou, que el e pecuarista, então el e conseguiu retirar essa economia que nós tínhamos no banco, mas foi muito dificultoso, porque o governo conseguiu pegar muita coisa ....Então nessa aqui, eu acho que nessa aqui, não sei se estou certa ou errada, mas eu acho que é uma acusação, essa figura aqui, é uma acusação, apontando para cada um, que também, ou você trabalha, vocêtem, ou então vocênão tem. (F)

Também neste caso a relação que se estabelece éa de decepção ede prudência em relação ao Estado, diante de um contrato rompido, de direitos desrespeitados. $M$ as, analogamente à sra. $A$, o sujeito é apenas tangencialmente identificado com o "Brasil" em abstrato, mas as críticas estão centradas na atuação (que julga desleal) do governo: Brasil e governo são entidades distintas, a primeira acusando ou cobrando a segunda. D e resto, percebe-se uma compreensão pouco detal hada do querealmente ocorreu com as economias da sua família neste período, donde aparece-nos a possibilidade de interpretar essas colocações como um lapso, em que as associações do trabal ho da memória possivelmente resultaram numa narrativa falha em relação aos eventos que ocorreram.

Já começamos a adiantar alguns comentários em relação à categoria da identidade político-territorial, o que atesta a dificuldade (e a inutilidade) de separar rigidamente a análise de cada um desses aspectos nas falas.0 sr. I, por exemplo, ao an alisar estruturalmente a propaganda, adere ao seu postulado básico, tanto no aspecto da sensibilidade quanto no cognitivo: “( ...) o texto de chamada é um texto simpático: 'o Brasil espera que cada um cumpra com as suas obrigações'. Isso é verdade". N esta frase, podemos destacar o componente de identificação que se expressa nas atitudes responsivas da si mpatia e da atribuição de veracidade. Há adiante um indício das vivências posteriores do depoente na organização da sua opinião - memória sobre a peça publicitária: "M as pena que ninguém lêi isso, eles só lêem o texto aqui de chamada, mais nada.N ão é assim?" Na nossa inter pretação, essa idéia de que os enunciados completos das mensagens não são compreendidos e nem mesmo lidos pela maioria da população (que se repete nas leituras de outras peças publicitárias) pode ser em parte explicada pela sensação de comunicação bastante deficiente com 
a massa, que julgamos existir num dirigente do Partido Comunista Brasileiro, numa cidade politicamente conservadora, que não consegue conduzir o partido a nenhum sucesso eleitoral significativo (apesar do sucesso organizativo), numa trajetória que se encerra com o fechamento do partido na cidade. Para I - presumimos - , o "povo" que é el eitor na política municipal e leitor das peças publicitárias é um "outro" ("eles só lêem o texto aqui de chamada") , é um suj eito com o qual a comunicação sofre consideráveis perdas entre o emissor e o receptor. Essa percepção é inerente à incompreensão dos propósitos do sr. I, enquanto militante e dirigente de um partido que não consegue ser bem-sucedido. Em outras palavras, este "povo" é um "outro" que não "nos" entende, que não participa das esferas das quais "nós" participamos; há uma defasagem entre a mente deste sujeito coletivo ea "nossa". I afirma que "Todo cara comunista é um sujeito de mente avançada (...)", ou seja, tem uma mente que está em outro tempo e que geralmente não logra comunicar-se de modo eficiente, não pela deficiência do processo comunicativo, mas pela ausência de um código que seja comum com os receptores.

$\mathrm{N}$ a leitura da sra. $\mathrm{D}$, também aparece uma consideração inicial que é re ferente à identidade político - territorial eà atitude daí decorrente: “ (...) fora da figura eu vejo um país rico, promissor, que teria assim grandes possibilidades de desenvolvimento, etc." Aparece aqui um componente do imaginário nacional que foi comentado na primeira parte deste trabalho, no qual ocorre o amál gama da idéia de "país do futuro" e de "gigante" em termos de extensão territorial e riquezas naturais, potencial idades adormecidas que se manifestarão um dia. Estas imagens são freqüentes nos depoimentos, como vere mos adiante, indicando um aspecto consolidado do imaginário (e da consciência histórica, porque se trata de visões que envolvem o tempo do grupo), que é habitual e habilmente utilizado pela propaganda do período.

No trecho transcrito a seguir, podemos identificar al guns aspectos das relações de cidadania tais como são compreendidas pela depoente:

Não era comum essa frase, de cumprir as obrigações. Eles que tinham que cumprir. Acho que cumpria, mas não tinha essa frase.

O Brasil espera ... Pois é,mas o que nós esperamos do Brasil,me conte? 0 Brasil espera! Nós que temos que esperar, enão é do Brasil,é do povo que está mandando no Brasil. (A)

Fica clara aí a falta de reciprocidade dos deveres entre o indivíduo ea instituição, e pode-se afirmar que $A$ desmonta o Brasil como sujeito oculto, ao afirmar que quem deve satisfações não é o Brasil, mas "o povo que está mandando". Este "povo" composto de mandatários, tradução do grupo formado 
pelos governantes e seus apoiadores/influenciadores, é denominado na segunda frase como "eles", mas não se trata do mesmo sujeito que aparece no final desse fragmento transcrito, pois o verbo para "eles" está no passado, e para o "povo que está mandando" está no presente. Interpretamos este arranjo como uma indulgência para com os governos militares, que aparece em outra parte do depoimento.

Para o sr. H, entretanto, preso e profissionalmente prejudicado pelo re gime, não há indulgência al guma:

Bom, o que que é: "O Brasil espera que cada um cumpre suas obrigações". É um slogan.N ão é um ame-o ou deixe-0, é um slogan, mas é cheio de palavras vazias. Quero saber o que cada um faz pelo Brasil. Eu provo que eu sou útil à comunidade. Nesses 45, 55 anos de profissão, eu provo o que eu fiz pela comunidade. Estou fazendo, continuo fazendo. Tá bom? Agora esses que falam pelos cotovelos e que nunca fizeram nada pela comunidade? Só tão querendo amealhar cada vez mais dinheiro, mais recurso, mais lucro. Veja bem,o empresário, a tal da globalização. Hoje com a tal da tecnologia que está avançando em todos os ramos da atividade humana, com a automação, o que é que acontece? O s empresários, os grandes industriais tão procurando atualizar a sua entidade por causa da concorrência, pra produzir bens mais acessíveis e que sejam mais baratos, o custo para ele ter maior lucro. Então, se ele tiver que dispensar 15, 20,50,100, ou 500, ou ... ele dispensa! Elenão está se importando com o que vai acontecer com esses operários demitidos, el e está pensando na sua empresa. E as conseqüências sociais do desemprego? Ele não vai resolver. Então não éa iniciativa privada que vai resolver, não éa economia de mercado que vai resolver, tá entendendo? Não éa economia de mercado que vai resolver. $(H)$

A propaganda,para el e,carece deautenticidade ("palavras vazias"), pois os que a elaboraram e apoiaram (os apoiadores do regime, subentende-se,ao ler as memórias de H sobre o período) não seriam tão úteis à comunidade como ele. Assim, o sr. H traça um padrão de relacionamento desejável entre 0 indivíduo e o grupo, um critério de civismo conseqüente: considerando a sua atuação profissional como desvinculada da sede delucro (prestou serviços gratuitos aos que não tinham recursos desde o início da carreira até o presente), ele vincula o comportamento do cidadão ideal que imagina a uma priorização do ser humano e do bem-estar em detrimento do lucro e da exploração do trabalho. Esta definição é feita pelo contraste com o seu contrário, que para $\mathrm{H}$ é o comportamento dos empresários e da economia de mercado.

U ma cobrança semelhante de uma atitude não egoísta aparece na fala do entrevistado a seguir, que traça uma espécie de projeto normativo decidadania: 
N essa figura aqui eu fico achando que a pessoa tá pensando que o Brasil tá ficando pequenininho, fazendo um desenho com os dois dedos,mostrando que 0 Brasil tá pequeno, precisa expandir o Brasil.Que se todo mundo cumprir as obrigação, fazer as coisas como deve ser feito, procurar esses político ricão que não tem mais onde pôr dinheiro, que consegue um empréstimo aí do governo, que é uma enormidade, que podia servir pra muita gente, eles pegam. Claro! É a gente que paga. Por isso está esses processo aí, essa barulhada, todas essas coisas superfaturadas que eles fazem, uma porção de gente bem rico que chega ali e pá, roubar uma fortuna que podia servir para melhorar o Brasil,né? É um, dois três, que sai, nem fica aqui, a gente sabe que tá acontecendo isso, então eu acho que os brasileiros cumprir a obrigação deles, porque lá eles mandam, que fazer essas malandragens, roubar o dinheiro do Brasil, pro Brasil continuar pagando juros, que não tem, acho que nunca vai conseguir pagar esses juros seo povo não mudar, né? (G)

O grupo que sofre a crítica de $G$ pode ser identificado, a partir deste tre cho transcrito, como os que combinam a condição de políticos e de ricos (ou pelo menos das atribuições pouco honrosas que $G$ aponta para os políticos); com esse grupo, o Sr. G não estabel ece distância ou alteridade: eles são "brasileiros" que precisam cumprir a obrigação, são "o povo" que precisa mudar, ou "o político" que precisa mudar. Por outro lado, descolando uma identidade total, esse leitor afirma que é deles a missão de "tratar bem dos brasileiros". N ote-se aí a ausência do sujeito falante na resolução dos problemas coletivos, que é algo significativo a ser retomado adiante...

A interpretação do sr. G sobre a figura também se distingue da que interpretamos como esperada pelos elaboradores, na medida em que ele vê um gesto que não é de intimação / intimidação, mas de indicação de que o País precisa ser expandido. Faz a ponte com outra imagem cara à propaganda política do período, que éa do "Brasil Grande", do imperativo de desenvolvêlo, engrandecêlo. M ais uma vez, o "comprar" é "comprado" como "cumprir", e o sr. G delineia o significado compreendido da frase como a responsabilidade individualizada para uma conduta ética na atividade econômica. Isso expressa,apesar dos caminhos interpretativos inesperados que $G$ toma para chegar às suas afirmações, a internalização do padrão de comportamento político estimulado como ideal pela propaganda do regi me,cal cado na desmobilização, na despolitização e na integração do indivíduo à cidadania / nacionalidade primordialmente pe lo trabalho honesto, responsável e politicamentesilente.

Essa crítica do sr. G pressupõe uma horizontalidade na relação com os homens públicos, e essa horizontalidade passa por considerá-los como “brasileiros" e como "povo". Essa perspectiva de compartilhar identidade com os 
detentores do poder não está presente na fala a seguir. Pelo contrário, essa fala constitui um exemplo de uma compreensão de absoluta verticalidade na relação com "eles":

Ah, a da mão. Isso mostra um autoritarismo, não sei. Impõe assim uma segurança, uma firmeza, pelo menos a figura,né? Bom, ele impõe as leis,né,e daí cada um cumpra conforme pode, conforme deve, as obrigações,né, que tem que cumprir.

ENTREVISTADOR: A senhora falou é ... eles. Eles quem?

O governo, o presidente lá, por intermédio de seus assessores, impõe as leis e cada um deve,cada um cump resuas obrigações,né? Ele impõe e espera que cumpram, que seja cumprido, de acordo conforme é mandado, né? M as não ébem assim queé cumprido. Que se fosse todo mundo cumprisse conforme manda talvez não era tão bagunçado nesse país, né? (B)

A fala da sra. B e associa o autoritarismo com a segurança e a firmeza, 0 que nos leva a imaginar que não há para ela uma consideração negativa desse dito autoritarismo. As frases seguintes confirmam esta análise, quando a imposição das leis e o seu cumprimento passivo são como a expressão de um quadro natural e irreversível da relação entre o governo e o povo. Este poder, aliás, é identificado não no governo, mas especificamente no presidente,para o qual a atribuição de impor leis aparece de maneira tranqüila, e associada ao mando, absorvendo as funções normais do Legislativo numa democracia.Esta visão do papel do presidente aparece-nos como uma "seqüela" para o imaginário nacional, não resultante só do período em estudo, mas da maior parte da vida política nacional, em que o poder centralizou-se no Executivo, e mais especificamente na figura pessoal de seus mandatários máximos.0 mesmo se pode dizer da oposição entre a obediência e desordem, uma existindo apenas na ausência da outra, dispostas como antônimos. A depoente entende o país como "bagunçado", provavelmente como resultado da subversão da ordem que indicou: o presidente impondo leis, mandando, e as pessoas cumprindo. Há, portanto, uma percepção da democratização do País como perversão da lógica autoritária, que garantia segurança, e a degeneração do convívio nacional para a ausência de ordem atual.

É interessante notar ainda como a análise do sr. C sobre a propaganda em questão descreve em parte o posicionamento da sra. E:

(...) porque lá se falava isso, cumprir seu dever, né? De brasileiro, bonzinho, quer dizer, aquele brasileiro que fica quieto, trabalha direitinho, que não reclama, e deixa a engrenagem andar. (C) 
O Brasil espera que cada um cumpra com suas obrigações". As obrigações que nós temos é ... eu acho, em primeiro lugar é com a nossa família, com os nossos familiares, nosso dever, nosso trabalho, a sociedade, nós temos muita obrigação principalmente com os menores,né,as pessoas de idade, que temos que ter obrigações, tem que ter assim um certo respeito da sociedade. Porque cada um, cada governo ... porque a gente pensa assim, o governo não fez isso, não fez aquilo, mas tem que pensar que ele também não [inaudível] e acima de tudo ele também tem um senhor acima dele que éJesus.Q uer dizer que nada vocêfaz sem a vontade del e.Q uer dizer que nós temos que ter obrigações, enquanto nós estamos morando aqui nesse mundo nós temos muitas obrigações. Eu acho que é isso aí, cumprir com as obrigações são essas partes, né? (E)

A sra.E faz uma interpretação social / moral (enão econômica) do comportamento que a peça publicitária recomenda,indicando uma responsabilização individual para com as pessoas em situação detutela, dependência ou fragilidade, sem colocar a obrigação do Estado de garantir direitos e assistência social.

Por fim, temos duas indicações sobre a consciência histórica, das falas das sras. A eE (citada logo acima):

Nós que temos que esperar, enão é do Brasil, é do povo que está mandando no Brasil. E não tem, não tem eles que ... achasse que queria acertar, não morreu, não mataram? Aquele que teve aquela periotonite no, no, no intestino ... aquilo não foi periotonite, foi tiro mesmo, eu sei como éque é. A gente escuta, que vive,né, o outro fala, qual era o nome dele, o presidente... A téfoi esse que ficou doente muito tempo, o Tancredo Neves.É, nem pôde governar. Aquele ia ser um governo bom. (A)

Na fala de A ficou explícita uma visão de história nesta depoente que privilegia o indivíduo extraordinário ocupando o poder como a chave para a transformação política, econômica e social. Decorre desta visão uma perspectiva que vê o poder dissimulado agindo nos bastidores e bloqueando a ação destes homens públicos através de ações de bastidores, complôs, conspirações que,através da violência secreta jamais revelada publicamente (mas que, de alguma maneira,é conhecida),silencia os que poderiam trazer a redenção nacional.

Na fala desta depoente, mesclam-se dois dos mitos políticos analisados por Giradet, o complô e o salvador ${ }^{27}$. Especialmente o primeiro, explica Giradet, tem uma permanência excepcional, repetindo-se freqüentemente por sua capacidade de tudo explicar em proveito de qualquer grupo social que se ar- 
me deste mito para elucidar o real, num método que se aproxima do exorcismo por possibilitar o desafio ao mal, no revelá-lo ao olhar de todos ${ }^{28}$, desencarnando earrancando-o às trevas do segredo. Entretanto, estamos aqui diante de uma elucidação do complô que não perde seu caráter de passividade política, porque só ilumina a política retrospectivamente, só esclarece um ponto no passado, eainda assim não éum exorcismo público, mas uma espécie de confissão privada cuja força sobre a história é nula: sua função é apenas dar ao portador o consolo de que ele não integra a desolada massa dos enganados eingênuos.

$\mathrm{Na}$ fala de $\mathrm{E}$ fica patente uma compreensão de história que a imagina conduzida pela divindade e suas forças sobrenaturais, perante a qual a ação dos homens - mesmo dos grandes homens - tem pouca importância. Isso nos coloca diante da presença de uma consciência histórica que é distinta daquela que Gadamer descreve, e queAgnes Heller considera como um estágio da consciência em que o tempo do grupo é visto como parte do mito universal ${ }^{29}$. Este estágio, para Heller, precede uma forma laica da consciência que coloca a humanidade na posição de sujeito único de sua própria história.

\section{EM SUMA}

M esmo considerando que este procedimento foi mais amplo, incluindo aí o levantamento do perfil biográfico de cada depoente, a leitura e a análise de várias outras peças publicitárias, não é possível levantarmos afirmações generalizantes. Em contrapartida, não é também possível dizer que o fato do grupo dos depoentes estar circunscrito a uma dada realidade no município de Ponta Grossa, não pode ser posto como limitador geográfico ou social das opiniões e das imagens que foram expostas. Supomos que o leitor que se disponha a entabular uma conversa breve com as pessoas que vivenciaram o período encontrará uma série de semelhanças com os depoimentos colocados neste texto.

O estudo aponta para al gumas necessidades no que se refere à pesquisa desta categoria de objetos. Em primeiro lugar, coloca-se a necessidade dos estudos que discutem a emissão demensagens ideológicas de considerarem também os receptores como sujeitos, capazes de traduzir e reelaborar as mensagens a partir de referenciais próprios, e que nunca são homogêneos dentro do grupo atingido pelas mensagens. Dentro ainda desta ordem de considerações, é preciso tomar as leituras como estruturalmente aberrantes, ou seja, diferentes ou não idênticas àquelas pretendidas pelos criadores das mensagens, mesmo quando estes consideram a heterogeneidade do seu público e 
criam peças destinadas a não se chocarem com a forma de pensar da maioria dos consumidores.

No que se refere à pesquisa sobre o ensino da H istória, cremos que este estudo reforça a necessidade do conhecimento das mensagens educativas nãoformais e seu papel na formação das idéias e imagens sobre a história na população, até porque os diferentes projetos nacionais implementados pelas elites são constituídos também por um projeto pedagógico sobre as demais classes sociais, que envolve a idéia que a coletividade faz de si própria no tempo e no espaço. Portanto, não é possível ver o ensino escolar da H istória como o foco central da formação do cidadão, mas como um dos poucos focos nos quais é possível o embate entre diferentes projetos e leituras do Brasil no tempo. Apenas considerando este quadro é que é possível pensar num trabaIho em que a disciplina $\mathrm{H}$ istória seja capaz de fazer frente às imagens estabe lecidas no senso comum e constituintes de uma memória histórica. É nesse contexto que é possível perceber que se não puder oferecer ao alunado as ferramentas do historiador - como a concepção da historicidade ou a perspectiva crítica diante da memória - , a disciplina incorrerá em crescente inutilidade, uma vez que aquele trabalho de constituição da memória histórica já não é mais prioritariamente dela. Já não se trata de optar politicamente por H istória ou memória histórica, trata-se de optar entre a manutenção ou não de algum significado da História nos bancos escolares.

\section{NOTAS}

* Este texto é uma síntese da tese de doutorado homônima defendida pelo autor no Programa de Pós-Graduação da Faculdade de Educação da Unicamp, sob a orientação da professora doutora Ernesta Zamboni, em março de 2000.

${ }^{1}$ Cf.DIAS, M aria de Fátima Sabino e CERRI, Luís Fernando. "H istória do ensino de História e História da América”. In CERRI, Luís Fernando e M ARTINS, M aria do Carmo (orgs.) Anais do III Encontro Nacional de Pesquisadores do Ensino de H istória. Campinas: Gráfica da FE/Unicamp, 1999, pp. 113-115.

2Esteposicionamento de Bergman é expresso no artigo "A H istória na Reflexão Didática". In Revista Brasileira de H istória. São Paulo, v. 9, n. 19, pp. 29-42, set. 89/ fev. 90.

${ }^{3}$ Para HELLER, Agnes em Uma Teoria da História. Rio de Janeiro: Civilização Brasileira, 1993, estar no tempo e no espaço é uma compreensão dada pela noção de mortalidade e pela noção de coletividade: só há significado em estar aqui e agora porque sabemos que um dia não mais estaremos ( seremos não-tempo e não-espaço), e porque sabemos que há o gênero humano, e que outros estiveram e estarão, antes e após nós. Estas são as percepções que acompanham o homem desde o seu surgimento enquanto ser racional,e que fundamentam a necessidade de uma consciência histórica. 
${ }^{4}$ GADAM ER, H ans-Georg. 0 problema da consciência histórica. Rio de Janeiro: Fundação Getúlio Vargas, 1998, p. 17.

${ }^{5}$ Idem, p. 18.

${ }^{6}$ GRAM SCI, Antônio. Concepção dial ética da história. 4ạ ed. Rio de Janeiro: Civilização Brasileira, 1981, passim.

${ }^{7}$ É a expressão de Antonio Tavares de JESU S ao comentar o senso comum, em sua obra Educação ehegemonia no pensamento deAntonio Gramsci. São Paulo/Campinas: Cortez/Editora da U NICAM P, 1989, p. 47.

${ }^{8}$ Estamos compreendendo por revistas informativas aquelas cujo formato é caracterizado pela paridade entre texto e ilustrações (e que em al guns casos - como a Fatos e Fotos e $M$ anchete - as ilustrações geral mente ocupam mais espaço que o texto) e que não são produzidas tendo em vista um público segmentado. Nesse sentido, diferenciam-se de revistas femininas ou masculinas, bem como de revistas que se organizam a partir deinteresses segmentados (como profissões, hobbies, etc.)

${ }^{9}$ Roland BARTHES. Societé,imagination, publicité, In BARTHES, Roland. 0 euvres completes. Paris: Seuil, 1994, pp. 513-514.

${ }^{10}$ FI GU EI REDO, Anna Cristina Camargo M oraes. "Liberdade éuma calça velha, azul edesbotada". Publicidade, cultura de consumo e comportamento político no Brasil (19541964). São Paulo: H ucitec, 1998, p. 130 e passim.

${ }^{11} \mathrm{~N}$ o sentido amplo que compreende os processos de informação e de formação que interagem com os indivíduos e grupos, e que portanto inclui, mas não se restringe aos momentos institucional e social mente reconhecidos elegitimados como educativos. N esse sentido, a vida é um contínuo processo educativo, tal como ocorre nas sociedades sem escola.

${ }^{12}$ Estamos compreendendo os enunciados enquanto unidades da comunicação verbal, tal como os define M ikhail BAKHTIN, no texto Os gêneros do discurso. In BAKHTIN , M ikhail.. Estética da criação verbal. São Paulo: M artins Fontes, 1997, pp. 277-326.

${ }^{13}$ ECO, U mberto. “Para uma investigação semiológica sobrea mensagem televisional” p. 369. In ECO, U mberto. A pocalípticos e integrados. São Paulo: Perspectiva,1976, pp. 365-386.

${ }^{14} \mathrm{Há}$ ainda um outro contexto do qual os leitores foram alijados, o que constitui ainda uma outra limitação à possi bilidade de reproduzir a reação original das pessoas às peças publicitárias. Trata-se do gesto envolvido na recepção da mensagem publicitária, no caso das revistas, que éa continuidade do ato da leitura entre as informações trazidas pelo suporte (a revista) e as publicidades em si, ato no qual todas as mensagens são igual mente tratadas,sejam ou não publicitárias, e ato enfim que implica "manter-se na superfície da imagem sem distinguir fundamentalmente seus conteúdos" (BARTHES, op. cit., p. 508). A natureza deste gesto leva a estabelecer uma relação imediata entre a publicidade e o imaginário. Como as peças sel ecionadas foram copiadas e apresentadas isoladamente, fora da revista em que se inseriam, este contexto e este gesto se perdem, e se transmutam para um outro, que é o relativo ao contexto de uma entrevista. 
${ }^{15} \mathrm{Cf}$. BOSI ,Ecléa. M emória e sociedade. Lembranças de velhos. 6ạ ed. São Paulo: Companhia das Letras, 1994., p. 59.

${ }^{16}$ LÜ DKE, M enga \& AN DRÉ, Marli. Pesquisa em educação: abordagens qualitativas. São Paulo: EPU, 1986, p. 19.

${ }^{17}$ HALBWACHS, M aurice. "A memória coletiva”. In Revista dosTribunais. São Paulo:Vértice, 1990, p. 51.

${ }^{18}$ BAKHTIN. Op. cit.., p. 297.

${ }^{19}$ - "Um enunciado concreto éum elo na cadeia da comunicação verbal de uma dada esfera. As frontei ras deste enunciado determinam-se pela alternância de sujeitos falantes. $0 \mathrm{~s}$ enunciados não são indiferentes uns aos outros,n em são auto-suficientes; conhecem-se uns aos outros, refletem-se mutuamente. São precisamente esses reflexos recíprocos que Ihes determinam o caráter. 0 enunciado está repleto de ecos e lembranças de outros enunciados, aos quais está vinculado no interior de uma esfera comum na comunicação verbal. 0 enunciado deve ser consider ado acima de tudo como uma resposta a enunciados anteriores dentro de uma dada esfera (a pal avra 'resposta' é utilizada aqui no sentido lato); refuta-0s, confirma-os, completa-os, baseia-seneles, supõe-nos conhecidos e, de um modo ou de outro, conta com eles." (idem, p. 316)

${ }^{20}$ Idem, p. 320.

${ }^{21}$ CANIVEZ, Patrice. Educar o Cidadão? Ensaios e textos. Campinas: Papi rus,1991, p. 122. DE DECCA, Edgar. “M emória e Cidadania”. In São Paulo (cidade). Secretaria M unicipal de Cultura. Departamento do Patrimônio Histórico. 0 direito à memória: patrimônio histórico e cidadania. São Paulo: DPH , 1992. N esse texto, o autor qualifica a ambigüidade ameaçadora deste fenômeno: "nem memória, porquealheia à experiência do vivido, nem história, porque destituída deseu valor crítico com relação ao passado". (p. 133). Vale a pena, ainda, citar GUYON et al. D es nations à la Nation Apprendre et conceptualiser. Paris, Institut N ational de Recherche Pédagogique, 1993 : “A memória seleciona os grandes episódios do passado, transforma os atores em heróis, oculta os eventos que prejudicaram a coesão do grupo (como guerras civis, grandes conflitos sociais, repressão do poder central,ocu pação estrangei ra...). A memória do grupo legitima o presente, constitui uma visão ideal do grupo, alimenta seu imaginário." (p. 47). Ressalvamos quelogo a seguir os autores esclarecem que a memória de que falam não é passado, nem história, mas uma faculdade de reminiscência seletiva a serviço da unidade do grupo, portanto bastantesemelhante ao que De Decca chama de memória histórica.

${ }^{22}$ Trata-se, a rigor, de uma campanha paraestatal, originada no aparato de repressão política da O ban (O peração Bandeirantes, deSão Paulo), mas que ganhou espaço rapidamente entre os apoiadores do regime, conforme esclarece FICO, Reinventando o 0 timismo Ditadura, propaganda e imaginário social no Brasil. Rio de Janeiro: Fundação Getúlio Vargas, 1997, p. 101,indo inclusive contra a linha geral da propaganda da Aerp (Assessoria Especial de Relações Públicas da Presidência da República), que era de conciliação e harmonização.

${ }^{23}$ BARTHES. Op. cit., p. 510.

${ }^{24}$ Essa discussão é conduzida, por exemplo, por CANIVEZ. O p. cit., p. 17 ess. 
${ }^{25} \mathrm{Cf}$. AnnaFiguel RED O. O p. cit.

${ }^{26}$ Sobre este ponto, éinteressante acompanhar a reflexão de Sílvia Hunold LARA (no texto Tiradentes ea nação esquartejada. In SÃO PAU LO (município). Pátria amada, esquartejada. São Paulo: Secretaria M unicipal de Cultura/D epartamento do Patrimônio Histórico, 1992, pp. 19-28), para a qual o esquartejamento de Tiradentes tem um significado muito forte, ao ser capaz de definir um aspecto que não é acessório, mas central à constituição da identidade nacional brasileira, embora isso seja sempre negado pelos que procuram edificar dentro de uma perspectiva tradicional e de cima para baixo: os brasileiros resultam de um processo em que os direitos são desrespeitados, como pedaços constitutivos do cidadão que dele são arrancados.

${ }^{27}$ GIRADET, M itos eM itologias políticas. São Paulo: Companhia das Letras,1987. Ressaltamos que no questionário escrito, A utilizou um filme de propaganda do Partido da Social Democracia Brasileira, exibido na época da entrevista,para exemplificar suas idéi as: "eles" (queela não soubeidentificar como o PSD B) estariam certos em sua comparação de que fazer as mudanças no Brasil é como cutucar uma colméia, pois existem interesses (não explicitados) que são muito poderosos, mas é preciso enfrentá-los. É interessante notar como esta propaganda utiliza de certa forma a mitologia do complô,sendo assumida por isso pela Sra. A, partidária desta explicação do mundo político.

${ }^{28}$ Idem, p. 55.

${ }^{29}$ HELLER. O p. cit., p. 16 ess. 